\title{
EMPOWERING THE COMMUNITY TO OVERCOME COVID-19 PANDEMIC IN TAIWAN AND THE SCIENCE - AN EXAMPLE OF ELECTROLYZED WATER
}

\author{
Chin-Kun WANG \\ Chung Shan Medical University, Taiwan \\ wck@csmu.edu.tw
}

\begin{abstract}
Serve Acute Respiratory Syndrome coronavirus 2 (SARS-CoV2) outbreak from the December 2019 in China has brought over 220 million infected cases and caused over 4.55 million of death. COVID-19 pandemic till now destroy the human health, communication and economics, uncountable loss and huge influence greatly impact this world. In the past period, many cities were locked down in most countries. The status significantly change the life style and business condition. Available alert systems for the prevention of COVID-19 infection are very critical for a country, and reduce the threat to life. Fortunately, Taiwan empowers the management and control of immigration to stop the outbreak of COVID-19 effectively. No lock down or any influence for this society until the middle of May 2021. A missing point from the flight crews brought a wave of local transmission on $15^{\text {th }}$ May. The highest infected cases were 550 per day (total population of Taiwan is 23 million). Fortunately, this outbreak is well controlled under the self-awareness of all citizens, wearing face mask, sanitary behavior promotion (proper cleaning and washing hands), vaccination, and quick and correct pandemic investigation and proper isolation successfully reduce the infected cases to 1-3 per day in two months. Till today, 16103 infected cases and 839 cases are found $\left(15^{\text {th }}\right.$ September). From the past experience, community empowering is very important to prevent the outbreak and continuous transmission of COVID-19. From the science view point, except vaccine, some technology materials could show great potential on this pandemic. Electrolyzed water $(\mathrm{EW})$ is a new type of cleaning and disinfecting agent obtained by electrolysis with dilute sodium chloride solution, it has low cost and harm to the human body and is also environmentally friendly. The anode produces acid electrolyzed water (AEW) and is mainly used to inhibit bacterial growth and disinfect. The cathode provides basic electrolyzed water (BEW), which is implemented to clean the surface of objects. EW is a powerful multifunctional antibacterial agent with a wide range of applications in the medicine, agriculture, and food industry. Studies in vitro and in vivo show that it has an inhibitory effect on pathogenic bacteria and viruses. Therefore, EW is used for the prevention of chronic diseases, and in recent years it has been discovered can be used to against infectious viruses. Not only animal experiments, but also clinical trials have also obtained more and more relevant research results, such as accelerating wound healing, oral health care, anti-obesity, lowering blood sugar, anti-cancer and anti-infectious viral diseases, etc. This chapter will summarize the application of EW in treating bacteria, viruses and the prevention of infectious and chronic diseases.
\end{abstract}

Key words: SARS-COV2, COVID-19 pandemic, community, electrolyzed water

\section{Empowering the community to overcome COVID-19 pandemic in Taiwan}

Taiwan CDC got the information about the outbreak of SARS-like problem before lunar new year (February 2020). A mask policy (making and distribution for all citizens) and correct soap washing hand promotion started immediately. On the other side was to strengthen the immigration control, especially for people moved from China, together with very detailed pandemic evaluation and suspected cases isolation. This policy completely stopped the local transmission and local in one week. The life and economic was maintained in normal condition. However, COVID-19 had out broken in the world at that time being.

The most important is to empower the community by all citizens and everyday news about the pandemic (Fig. $1 \& 2)$. Also the foot-print of the confirmed infected cases were announced to remind people ever stayed or stopped. The other one is to protect the community hospital from infection very seriously. All hospitals keep very good resources to treat the potential high amounts of patients.

\section{Introduction of electrolyzed water (EW)}

Compared with other places in the world, some areas of the world have obvious aging phenomenon. People rarely get sick, lead a healthy life, and have a relatively high average life expectancy. Many scholars have found that in these areas, there are many elderly people over 100 years old.
The forest coverage rate is high, the island is surrounded by green trees, and there is little industrial pollution. The water quality of the rivers and lakes and the surrounding sea area is superior. After years of research, researchers have finally succeeded in using electrolysis to produce high-quality healthy functional water. And this kind of functional water is the prototype of EW. Many studies show that electrolyzed water (EW) has many benefits. For example, it can effectively suppress many harmful bacteria (Hayashibara et al., 1994; Park et al., 2001). EW has been considered as a new type of disinfectant (electrolyzed water contains $\mathrm{HOCl}$ ) and cleaning agent (electrolyzed water contains $\mathrm{NaOH}$ ) in recent years (Rahman et al., 2016).

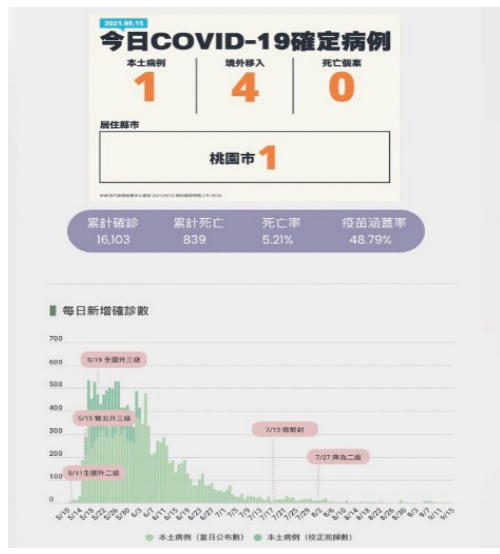

Figure 1. Daily infection and distribution. 


\begin{tabular}{|c|c|c|}
\hline 病例數 & 死亡人數 & \\
\hline 2.19億 & 455萬 & \\
\hline 地區 & 病例數 $\downarrow$ & $\begin{array}{l}\text { 死亡人 } \\
\text { 數 }\end{array}$ \\
\hline \multirow{2}{*}{ 口 台灣 } & 16,098 & 839 \\
\hline & +5 & \\
\hline \multirow{3}{*}{ 㷂 美國 } & 4140 萬 & 66.4萬 \\
\hline & +16萬 & $+2,652$ \\
\hline & 3330 萬 & 4. 4 . 萬 \\
\hline \multirow[t]{2}{*}{ - 印度 } & 2100萬 & 58.8 萬 \\
\hline & $+13,406$ & +731 \\
\hline \multirow[t]{2}{*}{ Q 巴西 } & 728萬 & 13.4萬 \\
\hline & $+26,251$ & +185 \\
\hline
\end{tabular}

Figure 2. The total infected cases in Taiwan and around the world

There are many studies using electrolyzed water in combination with other methods, such as organic acid, ultrasonic (Cichoski et al., 2019) or synergistic action of EW and mild heat, to make more effective sterilization. Therefore, the use of EW as a disinfectant is a major trend in the future. EW is the product of the electrolysis of a dilute $\mathrm{NaCl}$ or $\mathrm{KCl}-\mathrm{MgCl}_{2}$ solution in an electrolysis cell, within which a diaphragm (septum or membrane) separates the anode and cathode. During electrolysis, $\mathrm{NaCl}$ dissolved in deionized water dissociates into negatively charged chlorine $(\mathrm{Cl})$ and positively charged sodium $\left(\mathrm{Na}^{+}\right)$. At the same time, hydroxide $(\mathrm{OH})$ and hydrogen $\left(\mathrm{H}^{+}\right)$ions are formed. Negatively charged ions such as $\mathrm{Cl}^{-}$and $\mathrm{OH}^{-}$move to the anode to give up electrons and become oxygen gas $\left(\mathrm{O}_{2}\right)$, chlorine gas $\left(\mathrm{Cl}_{2}\right)$, hypochlorite ion $(\mathrm{OCl}-)$, hypochlorous acid $(\mathrm{HOCl})$, and hydrochloric acid, and positively charged ions such as $\mathrm{H}^{+}$and $\mathrm{Na}^{+}$move to the cathode to take up electrons and become hydrogen gas $\left(\mathrm{H}_{2}\right)$ and sodium hydroxide $(\mathrm{NaOH})$ (Fig. 3). EW has three main physical properties, available chlorine concentration (ACC), $\mathrm{pH}$ Value and oxidation-reduction potential (ORP), the difference in these properties will load the electrolyzed water into different sterilization effects. According to the different devices, electrolyte and electrolysis conditions, EW can be classified into the following categories: AEW, WAEW, NEW and BEW. The characteristic of EW is shown in Table 1

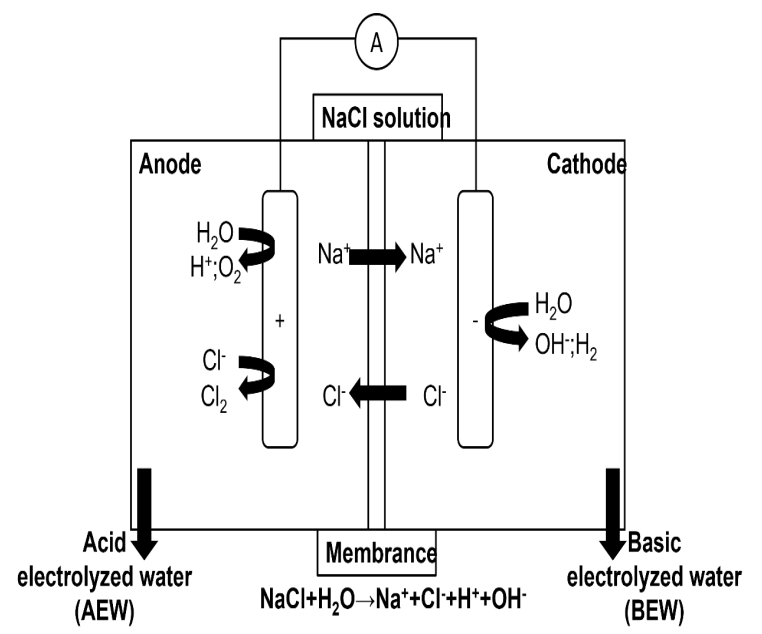

Figure 3. Schematic diagram of basic and acid electrolyzed water.

\section{Acid Electrolyzed Water (AEW)}

The acid electrolyzed water thus collected has a $\mathrm{pH}$ of about 2.2 to 2.7 , the ORP is greater than $1100 \mathrm{mV}$, and the ACC is $20-60 \mathrm{ppm}$, and it can inactivate most pathogenic bacteria (Ding et al., 2016; Venkitanarayanan et al., 1999). It can be called super oxidized water, strong oxidized water, strong acidic water, oxidized ion water. The main component is hypochlorous acid. AEW is a kind of medical product with strong sterilization effect (Sharma et al., 2003).

\section{Mechanism and disinfective effect of electrolyzed water}

The disinfective effect of EW mainly depends on its low $\mathrm{pH}$, high ORP, and the synergistic effect of $\mathrm{HClO}, \mathrm{Cl}_{2}, \mathrm{H}_{2} \mathrm{O}_{2}$ and hydroxyl $\left(\mathrm{OH}^{-}\right)$. Low $\mathrm{pH}$ will affect the permeability of cell membranes and prevent them from reproducing. High ORP will affect the metabolic compounds in bacterial cells and lead to cell death. $\mathrm{OH}$ and $\mathrm{H}_{2} \mathrm{O}_{2}$ can damage cell lipid membranes, denature proteins and prevent them from reproducing, destroy bacteria by cutting DNA to prevent enzyme activation (Kiura et al., 2002; Park et al., 2004). At present, the sterilization of EW has not been fully elucidated, but a model to explain the sterilization mechanism of EW has been roughly developed. First, after EW treatment, the morphology of the cell surface is changed from smooth, continuous,

\begin{tabular}{|c|c|c|c|c|}
\hline Type of EW & Solution & pH & ORP (mV) & ACC \\
\hline $\begin{array}{c}\text { Acid electrolyzed } \\
\text { water }\end{array}$ & $\mathrm{NaCl}$ water $(<0.2 \%)$ & $2-2.7$ & $>1100$ & $20-60$ \\
\hline $\begin{array}{c}\text { Weak acid } \\
\text { electrolyzed water }\end{array}$ & $\begin{array}{c}\mathrm{HCl} \text { water }(2-6 \%) / \\
\mathrm{The} \mathrm{mixture} \mathrm{water} \text { of } \\
\mathrm{NaCl} \text { and } \mathrm{HCl}\end{array}$ & $5-6.5$ & 850 & $10-30$ \\
\hline $\begin{array}{c}\text { Neutral electrolyzed } \\
\text { water }\end{array}$ & $\mathrm{NaCl}$ or $\mathrm{HCl}$ & $7-8$ & $750-900$ & $30-200$ \\
\hline $\begin{array}{c}\text { Basic electrolyzed } \\
\text { water }\end{array}$ & $\mathrm{NaCl}$ water & $10-13$ & $-800-900$ & $80-100$ \\
\hline
\end{tabular}

Table 1. The characteristic of EW 
and bright to rough, shrunken and even dissolved. At the same time, the bacterial protective barrier (cell wall and cell membrane) is attacked and destroyed by chlorine substances, which will increase the permeability of the cell membrane and the leakage of intracellular materials $\left(\mathrm{K}^{+}\right.$, protein and DNA) (Cheng et al., 2016; Ye et al., 2017).

\section{Antivirus effect of electrolyzed water}

The environment is full of various viruses. Some viruses can cause diseases. For example, most representative food-borne viruses are human norovirus, hepatitis A virus (HAV), and hepatitis B virus (HBV) which are contaminants in food and food processing facilities, which causes acute intestinal disease. Avian influenza (AI) is a disease caused by poultry influenza virus. This virus naturally exists in the digestive tract of birds and is generally not transmitted to humans. It has been found that the H5N1 avian influenza virus can be transmitted from birds to humans due to genetic mutations. EW has become popular in the food industry as a disinfection solution for food surfaces and food. It is reported that it has antibacterial effect on viruses, bacteria, fungi and spores.

\section{Potential of electrolyzed water on SARS-COV-2}

Takeda et al. (2020) evaluated the SARS-CoV-2 inactivation efficacy of AEW as an alternative disinfectant. The ratio of SARS-CoV-2 solution containing 1\% FBS and DDW or AEW to virus: test solution is 1: 1, 1:5 and 1:9 mixed reaction for 1 minute. AEW potently inactivated SARS-CoV-2 using 9 times volume of SARS-CoV-2 solution, and the viral titer of AEW-treated SARS-CoV-2 solution was below the detection limit ( $\geq 99.99 \%$ inactivation; decrease of $\geq 4.25 \log _{10}$ TCID $_{50} /$ $\mathrm{mL}$ ). However, when using 5 times the volume, its activity decreases. This result indicates that the rapid antiviral effect of AEW depends on the concentration of ACC, and the aging AEW, which is almost lost by ACC, does not show the ability to inactivate SARS-CoV-2. A simple acidic solution without ACC will not inactivate SARSCoV-2.

\section{References}

Cheng, X., Tian, Y., Zhao, C., Qu, T., Ma, C., Liu, X., \& Yu, Q. (2016). Bactericidal effect of strong acid electrolyzed water against flow enterococcus faecalis biofilms. Journal of endodontics, 42(7), 1120-1125.

Cichoski, A. J., Flores, D. R. M., De Menezes, C. R., Jacob-Lopes, E., Zepka, L. Q., Wagner, R., ... \& Campagnol, P. C. B. (2019). Ultrasound and slightly acid electrolyzed water application: An efficient combination to reduce the bacterial counts of chicken breast during pre-chilling. International journal of food microbiology, 301, 27-33.

Ding, T., Ge, Z., Shi, J., Xu, Y. T., Jones, C. L., \& Liu, D. H. (2015). Impact of slightly acidic electrolyzed water (SAEW) and ultrasound on microbial loads and quality of fresh fruits. LWT-food Science and Technology, 60(2), 1195-1199.

Fang, J., Cannon, J. L., \& Hung, Y. C. (2016). The efficacy of EO waters on inactivating norovirus and hepatitis A virus in the presence of organic matter. Food Control, 61, 13-19.

Hayashibara, T. (1994). A study of the disinfection/ microbiocidal effects of electrolyzed oxidizing water. Japan J. Med. Technol., 43, 555-561.

Hoffmann, S., Batz, M. B., \& Morris Jr, J. G. (2012). Annual cost of illness and quality-adjusted life year losses in the United States due to 14 foodborne pathogens. Journal of food protection, 75(7), 12921302.

Hsu, S. Y. (2005). Effects of flow rate, temperature and salt concentration on chemical and physical properties of electrolyzed oxidizing water. Journal of Food Engineering, 66(2), 171-176.

Leblanc, D., Gagné, M. J., \& Brassard, J. (2021). Effectiveness of water and sanitizer washing solutions for removing enteric viruses from blueberries. Food Control, 126, 108043.

Park, B. K., Oh, M. H., \& Oh, D. H. (2004). Effect of electrolyzed water and organic acids on the growth inhibition of Listeria monocytogenes on lettuce. Korean Journal of Food Preservation, 11(4), 530-537.

Park, C. M., Hung, Y. C., Doyle, M. P., Ezeike, G. O. I., \& Kim, C. (2001). Pathogen reduction and quality of lettuce treated with electrolyzed oxidizing and acidified chlorinated water. Journal of Food Science, 66(9), 1368-1372.

Podolak, R. K., Zayas, J. F., Kastner, C. L., \& Fung, D. Y. C. (1996). Inhibition of Listeria monocytogenes and Escherichia coli O157: $\mathrm{H} 7$ on beef by application of organic acids. Journal of food protection, 59(4), 370373.

Rahman, S. M. E., Ding, T., \& Oh, D. H. (2010). Effectiveness of low concentration electrolyzed water to inactivate foodborne pathogens under different environmental conditions. International journal of food microbiology, 139(3), 147-153.

Tamaki, S., Bui, V. N., Ngo, L. H., Ogawa, H., \& Imai, K. (2014). Virucidal effect of acidic electrolyzed water and neutral electrolyzed water on avian influenza viruses. Archives of virology, 159(3), 405-412.

Takeda, Y., Uchiumi, H., Matsuda, S., \& Ogawa, H. (2020). Acidic electrolyzed water potently inactivates SARSCoV-2 depending on the amount of free available chlorine contacting with the virus. Biochemical and Biophysical Research Communications, 530(1), 1-3. 
Venkitanarayanan, K. S., Ezeike, G. O., Hung, Y. C., \& Doyle, M. P. (1999). Efficacy of electrolyzed oxidizing water for inactivating Escherichia coli O157: H7, Salmonella enteritidis, and Listeria monocytogenes. Applied and environmental microbiology, 65(9), 4276-4279.

World Health Organization. (2021). Report Coronavirus disease (COVID-2019) situation reports. WHO (Accessed on March 19, 2020). Online Version.
Ye, Z., Wang, S., Chen, T., Gao, W., Zhu, S., He, J., \& Han, Z. (2017). Inactivation mechanism of escherichia coli induced by slightly acidic electrolyzed water. Scientific reports, 7(1), 1-10.

Zhu, N., Zhang, D., Wang, W., Li, X., Yang, B., Song, J., ... \& Tan, W. (2020). A novel coronavirus from patients with pneumonia in China, 2019. New England journal of medicine. 